\title{
Review
}

\section{Gastrin, gastrin receptors and colorectal carcinoma}

The possibility that gastrin may play a role in the development of colorectal carcinoma has aroused considerable interest over the past decade. In early reports some colorectal carcinomas and colorectal carcinoma cell lines were shown to produce gastrin, ${ }^{1}$ to express gastrin receptors, ${ }^{2}$ and to respond mitogenically to exogenous gastrin. ${ }^{2}$ The most favoured explanation for these observations was an autocrine or paracrine loop in which gastrin was produced by the tumour, bound to tumour receptors, and stimulated tumour growth. However, gastrin may also have acted as an endocrine agent as hypergastrinaemia has been reported in a number of patients with colorectal carcinoma, although the source of the gastrin has not been defined. ${ }^{3-5}$ Further studies of the expression of gastrin ${ }^{6-8}$ and gastrin receptors ${ }^{910}$ in colorectal carcinomas and colorectal carcinoma cell lines, and of hypergastrinaemia in patients with colorectal carcinoma, ${ }^{11-15}$ indicated that the early positive reports were not universally correct. Recent information on the nature and source of the gastrin produced, and the discovery of novel receptors selective for non-amidated gastrins, makes it timely to reconsider the involvement of progastrin derived peptides in colorectal carcinoma.

\section{Synthesis, storage and secretion of gastrin in colorectal carcinomas}

There is now abundant evidence that most colorectal carcinomas synthesise progastrin. Gastrin mRNA has been detected by both polymerase chain reaction and northern hybridisation in colorectal carcinoma cell lines, normal human colonic mucosa and colorectal carcinomas. ${ }^{616-18}$ The gastrin mRNA is of low abundance but the major band of 0.7 kilobases is identical in sequence to antral gastrin mRNA. ${ }^{616}{ }^{17}$ There is, however, considerable disparity in the literature on the proportion of colorectal carcinomas that contain amidated gastrin (table 1). The variable efficiency of translation and extent of postranslational processing of gastrin in peptide producing tumours ${ }^{20}$ offers an explanation for some of the contradictory reports as assays for gastrin have frequently been confined to amidated forms. The processing of gastrin from progastrin to the amidated product involves a number of steps, which include endopeptidase and carboxypeptidase mediated cleavages, and which end in conversion of glycine extended gastrin to the amidated forms (fig 1). ${ }^{21}{ }^{22}$ Using either region specific antisera or processing independent analysis, ${ }^{20}$ which quantitates all molecular forms of gastrin irrespective of the degree of processing, progastrin or progastrin derived peptides are now being detected in $80-100 \%$ of colorectal carcinomas (table 1). The presence of non-amidated gastrin peptides in colorectal carcinomas has assumed greater importance with the recent reports that gastrin-gly has a growth promoting effect in a non-transformed colonic epithelial cell line, ${ }^{23}$ as well as in a pancreatic cancer cell line $e^{24}{ }^{25}$ and in fibroblasts ${ }^{26}$ and with the description of receptors capable of binding non-amidated gastrin. ${ }^{23} 2426$ In addition, transgenic mice expressing human progastrin in the liver had raised concentrations of plasma progastrin and a hyperplastic colonic mucosa. ${ }^{28}$ The nature of the receptor responsible for the proliferative effects of progastrin is completely unknown.

Hypergastrinaemia in patients with colorectal carcinoma has also been controversial. Early studies were not controlled for Helicobacter pylori status (a known cause of hypergastrinaemia), had small sample sizes with the results skewed by apparent outliers, and measured only amidated gastrin. ${ }^{14}{ }^{15}$ After controlling for these factors, we have confirmed that circulating amidated gastrin is not raised in patients with colorectal carcinoma, but have made the intriguing finding that circulating non-amidated gastrin is raised both in $H$ pylori positive (5.2-fold) and negative (2.3-fold) patients with colorectal carcinoma. ${ }^{15}$ The initial reports of a decrease in plasma gastrin following surgical resection of the colorectal carcinoma ${ }^{45}$ have not been confirmed however. ${ }^{1314}$ The low gastrin concentration in colorectal carcinomas, together with the increase in circulating partially processed gastrin, is consistent with constitutive secretion, whereby gastrin is not stored in a processed form in tumour cells, but is secreted from peptide containing vesicles by exocytosis. ${ }^{29}$ An alternative explanation is that colorectal carcinomas are secreting an agent such as gastrin-releasing peptide which stimulates the secretion of antral gastrin.

\section{Gastrin/cholecystokinin receptors in carcinoma tissue and on cell lines}

For gastrin to function as a growth promoting agent, specific receptors capable of transducing a mitogenic signal must be localised on the tumour. At least four receptors exist for gastrin and cholecystokinin (CCK). ${ }^{30}$ The classic CCK-A receptor on pancreatic acinar cells is selective for sulphated $\mathrm{CCK}_{8}$ (dissociation constant $\left(\mathrm{K}_{\mathrm{d}}\right)=20 \mathrm{pM}$ ), whereas the gastrin/CCK-B receptor on gastric parietal cells recognises gastrin ${ }_{17}$ and both sulphated and unsulphated $\mathrm{CCK}_{8}$ with approximately equal affinity $\left(\mathrm{K}_{\mathrm{d}}=2-6\right.$ $\mathrm{nM}$ ). Both $\mathrm{A}$ and $\mathrm{B}$ receptors are members of the family of receptors with seven transmembrane segments. Despite sharing $50 \%$ identity in sequence, the $\mathrm{A}$ and $\mathrm{B}$ receptors can be clearly distinguished by several selective antagonists. A low affinity gastrin ${ }_{17}$ binding site $\left(K_{d}=200 \mathrm{nM}\right)$ has also been described on colorectal carcinoma cell lines, ${ }^{91}$ identified as a $78 \mathrm{kDa}$ protein, ${ }^{32}$ and called the gastrin/CCK-C receptor. ${ }^{32}$ Surprisingly, the gastrin/ CCK-C receptor is unrelated to the $A$ and $B$ receptors in sequence, but belongs to a family of enzymes involved in the $\beta$-oxidation of fatty acids. ${ }^{33}$ The $\mathrm{C}$ receptor can also be distinguished from the $\mathrm{A}$ and $\mathrm{B}$ receptors by the fact that addition of a C-terminal glycine residue to gastrin ${ }_{17}$ does not affect binding. ${ }^{27} \mathrm{~A}$ novel high affinity receptor selective for glycine extended gastrin, with a different antagonist profile from the $A$ and $B$ receptors, has also been described on a rat pancreatic carcinoma cell line (AR4-2J), ${ }^{24}$ and on a non-transformed colonic epithelial cell line. ${ }^{23} \mathrm{~A}$ slightly different receptor, recognising both glycine extended and amidated gastrins with similar high affinity, has been reported on the mouse colon cell line CA, and on Swiss 3T3 fibroblasts. ${ }^{26}$ Definition of the relation of the novel receptors to each other, and to the gastrin/CCK-A, -B, and 
Table 1 Frequency of gastrin positive colorectal carcinomas

\begin{tabular}{llllll}
\hline \multirow{5}{*}{$\begin{array}{l}\text { No of } \\
\text { specimens }\end{array}$} & Progastrin positive & Gastrin-amide & Gastrin-gly & $\begin{array}{l}\text { Assay } \\
\text { method }\end{array}$ & Reference \\
\cline { 2 - 5 } & NM & 0 & NM & RIA & 4 \\
16 & 100 & 8 & ND & RIA & 6 \\
44 & 100 & 43 & 45 & RIA & 7 \\
15 & 100 & 100 & 100 & RIA & 8 \\
32 & 100 & 69 & 44 & RIA & 15 \\
23 & 87 & 97 & NM & IHC & 19 \\
\hline
\end{tabular}

RIA, radioimmunoassay; IHC, immunohistochemistry; ND, not detected; NM, not measured.

\section{Preprogastrin $\square-\mathrm{R}-\mathrm{R}-\square-\mathrm{K}-\mathrm{K}-\square / \mathrm{Z} / \mathrm{A}-\mathrm{G}-\mathrm{R}-\mathrm{R}-\square$ \\ Signal peptidase $\downarrow$ (Endoplasmic reticulum) \\ Progastrin $\quad \square-R-R-\square-K-K-\mathbb{Z}$-G-R-R- $\square$}

Prohormone convertase $\downarrow$ (Early immature granules)

Gastrin $_{34}$ gly

Peptidyl $\alpha$-amidating monooxygenase

$$
\square-\mathrm{k}-\mathrm{k} \text { VII/A-gly }
$$

Gastrin $_{34}$ -K-K-VII

Prohormone convertase $\downarrow$ (Mature granules)

Gastrin $_{17}$

EIIT

Figure 1 Progastrin processing. Preprogastrin is converted to gastrin ${ }_{34}$ gly by sequential removal of the signal peptide (black box), and cleavage at paired arginine $(R)$ residues by prohormone convertase $(s){ }^{21}{ }^{22}$ Amidation of gastrin ${ }_{34}$ gly is followed by cleavage at the paired lysine $(K)$ residues to

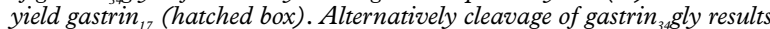
in gastrin gly. Note that gastrin $_{17}$ gly may be a distinct end product, which in rat antrum at least is not converted to gastrin ${ }_{17}^{22}$ The regions of the cell in which the processing steps occur are shown in brackets.

-C receptors, will require data on their size from cross-linking experiments and on their amino acid sequence from cloning experiments.

Controversy exists over whether most colorectal carcinomas or colorectal carcinoma cell lines express the gastrin/CCK-B receptor (summarised in table 2). Although Thompson's group ${ }^{34}$ detected high affinity gastrin binding sites on over $50 \%$ of human colorectal carcinomas, recent studies have not detected high affinity gastrin binding in resected human colorectal carcinomas, ${ }^{35} 36$ and mRNA encoding the gastrin/CCK-B receptor was detected in less than $20 \%$ of specimens. ${ }^{35}{ }^{37}$ Similarly, although binding sites for the gastrin/CCK-B receptor antagonist L365,260 were detected on all four human colorectal carcinoma cell lines, ${ }^{38}$ gastrin binding sites were found on only one of 10 human colorectal carcinoma cell lines, ${ }^{10}$ and mRNA encoding the gastrin/CCK-B receptor was present in only one (LoVo) of eight colorectal carcinoma cell lines tested. ${ }^{37}$ In agreement with this observation gastrin dose dependently increased LoVo cell number ${ }^{39}$ and DNA synthesis, ${ }^{37}$ but did not affect proliferation of the other eight colorectal carcinoma cell lines tested. ${ }^{37}$ Although few studies of CCK binding in human colorectal carcinoma have been undertaken, the data available suggest that CCK-A receptor expression in such tumours is rare (table 2). ${ }^{36}$ Taken together these findings suggest that CCK-A and gastrin/CCK-B receptors are present in only a small subset of colorectal carcinomas.

\section{Gastrin as an autocrine growth factor}

Gastrin is an established growth factor for the non-antral gastric mucosa, ${ }^{40}$ but proliferative effects on the normal mucosa of the small and large intestine, or on the development of colorectal carcinoma, are controversial. ${ }^{30} 41$ For example, patients with hypergastrinaemia associated with the Zollinger-Ellison syndrome have an increased rate of colonic mucosal cell proliferation, but do not have an increased prevalence of colonic adenomas. ${ }^{42}$ Similarly, patients with hypergastrinaemia associated with pernicious anaemia do not have an increased long term risk of colorectal carcinoma, ${ }^{43}$ although the risk may be increased in the first five years after diagnosis. ${ }^{44}$ Variations in the source and forms of gastrin may be responsible for these contrasting viewpoints as the observation that overexpression of intact progastrin in transgenic mice increased colonic mucosal proliferation suggests that biological activity is not confined to the amidated or glycine extended forms. ${ }^{28}$

The growth of some colorectal carcinoma cell lines both in culture and as xenografts is stimulated by exogenous and endogenous hypergastrinaemia, ${ }^{30}{ }^{45}$ and considerable interest has therefore been generated by the hypothesis that progastrin derived peptides may be acting as autocrine growth factors in colorectal carcinoma. In the autocrine model (fig 2) a cell synthesises its own growth factor, which is released into the surrounding medium. Binding of the growth factor to cell surface receptors then results in the transmission of a mitogenic signal to the cell nucleus, with a consequent increase in cell proliferation. The most convincing evidence for the involvement of progastrin derived peptides in an autocrine loop is the observation that expression of antisense gastrin mRNA reduced both growth and tumorigenicity of the colorectal carcinoma cell lines Colo 320 and HCT $116,{ }^{46}$ and growth of the conditionally immortalised mouse colon cell line YAMC. ${ }^{23}$ In contrast, growth of the colorectal carcinoma cell line Colo 205A, which expressed negligible amounts of gastrin mRNA, was unaffected by expression of antisense gastrin mRNA. ${ }^{46}$ The antisense experiments demonstrate that progastrin derived peptides act as autocrine growth factors in colorectal carcinoma cell lines, but do not define the form of progastrin derived peptides or the nature of the receptor involved in the loop.

The existence on colorectal carcinoma cell lines of an autocrine loop involving amidated gastrin and the gastrin/ CCK-B receptor (fig 2A) does not seem to be a common phenomenon. As discussed in the last section, most colorectal carcinoma cell lines do not express gastrin/CCK-B receptors. In addition the selective gastrin/CCK receptor antagonists L364,718 and L365,260 had no effect on proliferation of colorectal carcinoma cell lines at concentrations sufficiently high to saturate CCK-A and gastrin/ CCK-B receptors, respectively. ${ }^{48}{ }^{49}$ Antisera directed against the common C-terminal tetrapeptide of gastrin and CCK inhibit the proliferation of only a small proportion of colorectal carcinoma cell lines. ${ }^{13150}$

The possibility of an alternative autocrine loop which utilises non-amidated gastrins (fig 2B) should also be considered. Such peptides have been demonstrated in colorectal carcinoma specimens, as discussed in the section on synthesis and secretion. In the case of the mouse colon cell line YAMC, proliferation is partially inhibited by an antibody selective for glycine extended gastrin, but not by an antibody selective for amidated gastrins. ${ }^{23}$ Furthermore, YAMC cells do not bind amidated gastrin, but do express

Table 2 Frequency of gastrin/CCK receptor positive colorectal carcinomas

\begin{tabular}{|c|c|c|c|c|c|c|c|}
\hline \multirow[b]{3}{*}{$\begin{array}{l}\text { No of } \\
\text { specimens }\end{array}$} & \multicolumn{6}{|c|}{ Per cent positive } & \multirow[b]{3}{*}{ Reference } \\
\hline & \multicolumn{2}{|c|}{ Gastrin binding } & \multirow[b]{2}{*}{$\begin{array}{l}C C K \\
\text { binding }\end{array}$} & \multicolumn{3}{|c|}{ Gastrin/CCK receptor $m R N A$} & \\
\hline & $\begin{array}{l}\text { High } \\
\text { affinity }\end{array}$ & $\begin{array}{l}\text { Low } \\
\text { affinity }\end{array}$ & & $A$ & $B$ & $C$ & \\
\hline 67 & 57 & NM & NM & NM & NM & $\mathrm{NM}$ & 34 \\
\hline 112 & 0 & 36 & NM & NM & 11 & 75 & 35 \\
\hline 22 & 0 & NM & 0 & NM & NM & NM & 36 \\
\hline 10 & NM & NM & NM & NM & 20 & NM & 37 \\
\hline
\end{tabular}

NM, not measured 
A

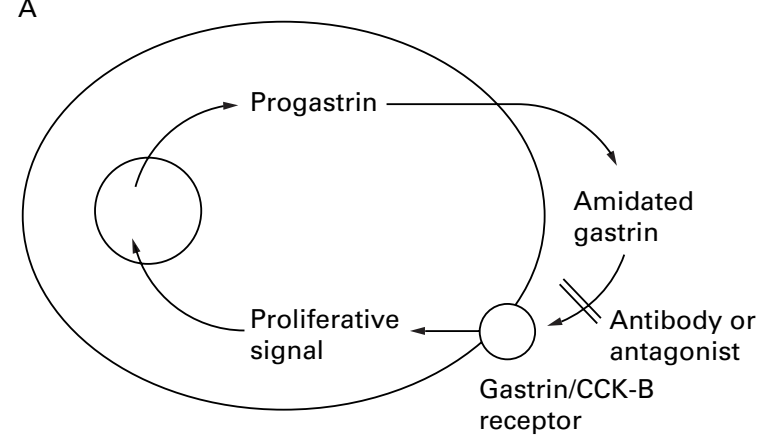

B

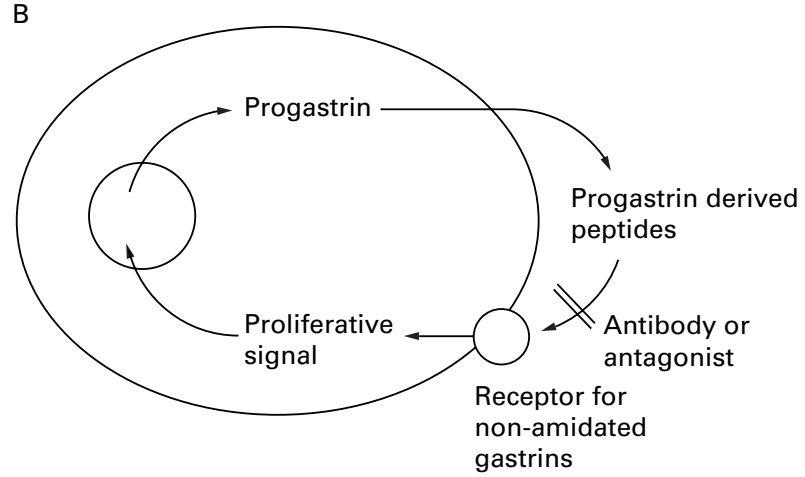

Figure 2 Autocrine growth loops involving progastrin derived peptides. At least two classes of autocrine growth loops involving progastrin derived peptides are possible. In both classes colorectal carcinoma cells produce and process progastrin, and the progastrin derived peptides are released into the surrounding medium. Binding of progastrin derived peptides to a specific receptor then results in an increase in cell proliferation. (A) In class I the cells secrete mature amidated gastrin, and express the gastrin/CCK-B receptor. The absence of gastrin/CCK-B receptors from most colorectal carcinoma specimens (table 2) and from colorectal carcinoma cell lines suggests that class I loops are infrequent. (B) In class II processing of progastrin is incomplete, and the cells express a surface receptor selective for non-amidated forms of gastrin, such as the receptor for glycine extended gastrins first described by Yamada and coworkers on the surface of the rat pancreatic carcinoma cell line AR4-27. ${ }^{24}$ In principle, either loop could be blocked by expression of antisense gastrin $m R N A,{ }^{23}{ }^{46}$ by antibodies against the appropriate progastrin derived peptides ${ }^{23}{ }^{47}$ or their receptors, or by selective receptor antagonists. Such antagonists have not yet been described for receptors for non-amidated gastrins.

a receptor selective for glycine extended gastrin, ${ }^{23}$ similar to the receptor first described by Yamada and coworkers on the rat pancreatic carcinoma cell line AR4-2J. ${ }^{24}$ Thus YAMC cells seem to utilise non-amidated progastrin derived peptides, and a receptor selective for glycine extended gastrin, in an autocrine loop.

The anti-proliferative effects of the non-selective gastrin/ CCK receptor antagonists proglumide and benzotript on colorectal carcinoma cell lines in vitro, ${ }^{31}$ and on colorectal carcinomas grown as xenografts in nude mice ${ }^{51}$ and rats, ${ }^{52}$ seem to be mediated by a completely different mechanism as the receptor for glycine extended gastrins does not recognise either antagonist. ${ }^{23}$ In fact, a comparison of inhibitory potencies suggests that the low affinity gastrin/CCK-C receptor is the probable target as in this case binding of gastrin to the gastrin/CCK-C receptor is blocked by proglumide and benzotript, but unaffected by L364,718 and L 365,260. ${ }^{32}$ Interestingly, inhibitory effects of proglumide on proliferation have also been described on fibroblasts $s^{53}$ and on cell lines of diverse origin, ${ }^{55}$ in agreement with the widespread tissue distribution of the gastrin/CCK-C receptor (Mantamadiotis and Baldwin, unpublished data). Clear definition of the role of the gastrin/CCK-C receptor in the autocrine effects of progastrin derived peptides will require the development of potent and selective antagonists.

\section{Therapeutic possibilities}

The presence of the autocrine gastrin loops described earlier suggests that gastrin/CCK receptor antagonists might be useful in the treatment of colorectal carcinoma. The non-selective antagonist proglumide inhibited the growth of colorectal carcinoma cell lines in vitro ${ }^{31}$ and in vivo. ${ }^{51} 52$ However, a clinical trial of proglumide in patients with gastric carcinoma did not reveal any benefits, perhaps because the concentrations achieved were not sufficient to saturate gastrin/CCK receptors. ${ }^{56}$ Other more potent gastrin/CCK receptor antagonists have also been shown to inhibit the growth of colorectal carcinoma cell lines in vitro, ${ }^{48} 5758$ and of primary human colorectal carcinomas in vitro $^{59}$ and in athymic rats, ${ }^{45}$ but have not yet been subjected to clinical trials. The observation that most colorectal carcinomas do not express gastrin/CCK-B receptors, however, indicates that it will be unlikely that gastrin/CCK-B receptor selective antagonists will be a general treatment for colorectal carcinoma.

In contrast, antibodies directed against gastrin may be useful for treatment of colorectal carcinoma. As mentioned earlier, antibodies recognising the C-terminal amidated tetrapeptide common to both gastrin and CCK inhibit the proliferation of some, ${ }^{131}$ but not all, ${ }^{49}$ colorectal carcinoma cell lines. Conversely, proliferation of the mouse colon cell line YAMC is inhibited by antibodies recognising glycine extended, but not amidated, gastrins. ${ }^{23} \mathrm{~A}$ particularly promising development has been the demonstration that preimmunisation of rats with Gastrimmune (a conjugate of amino acids 1-9 of gastrin $_{17}$ and diphtheria toxoid) reduced the in vivo growth of the rat colorectal carcinoma cell line DHDK $12 .^{47}$

\section{Summary}

Most colorectal carcinomas produce progastrin, but only a subset of colorectal carcinomas expresses classic gastrin/ CCK-B receptors. Novel gastrin/CCK receptors capable of binding non-amidated forms of progastrin derived peptides have also been described in the past three years. High affinity antagonists selective for the non-classic gastrin/ CCK receptors are required urgently, in order to test the working hypothesis that one or more of the novel receptors is the target for the autocrine proliferative effects of progastrin derived peptides. In the longer term the interaction between progastrin derived peptides and the proteins altered by the cascade of genetic mutations associated with the development of colorectal carcinoma ${ }^{60}$ needs to be resolved. Demonstration of proliferative effects of progastrin derived peptides in the early stages of the adenomacarcinoma sequence might have diagnostic and therapeutic benefits.

G S BALDWIN

A SHULKES

Department of Surgery,

A\&RMC, Austin Campus,

Locked Bag 25, Heidelberg,

Victoria 3084, Australia

Correspondence to: Dr Baldwin (email: gsb@austin.unimelb.edu.au).

1 Hoosein NM, Kiener PA, Curry RC, et al. Evidence for autocrine growth stimulation of cultured colon tumor cells by a gastrin/cholecystokinin-like peptide. Exp Cell Res 1990;186:15-21.

2 Singh P, Rae-Venter B, Townsend CM, et al. Gastrin receptors in normal and malignant gastrointestinal mucosa: age-associated changes. $\mathrm{Am} \mathcal{F}$ Physiol 1985;249:761-9.

3 Smith JP, Wood JG, Solomon TE. Elevated gastrin levels in patients with colon cancer or adenomatous polyps. Dig Dis Sci 1989;34:171-4.

4 Wong K, Beardshall K, Waters CM, et al. Postprandial hypergastrinaemia in patients with colorectal cancer. Gut 1991;32:1352-4.

5 Seitz J-F, Giovannini M, Gouvernet J, et al. Elevated serum gastrin levels in patients with colorectal neoplasia. f Clin Gastroenterol 1991;13:541-5.

6 Van Solinge WW, Nielsen FC, Friis-Hansen L, et al. Expression but incomplete maturation of progastrin in colorectal carcinomas. Gastroenterology 1993;104:1099-107. 
7 Nemeth J, Taylor B, Pauwels S, et al. Identification of progastrin derived peptides in colorectal carcinoma extracts. Gut 1993:34:90-5.

8 Kochman ML, DelValle J, Dickinson CJ, et al. Post-translational processing of gastrin in neoplastic human colonic tissues. Biochem Biophys Res Commun 1992;189:1165-9.

9 Weinstock J, Baldwin GS. Binding of gastrin ${ }_{17}$ to human gastric carcinoma cell lines. Cancer Res 1988;48:932-7.

10 Frucht H, Gazdar AF, Park J-A, et al. Characterization of functional receptors for gastrointestinal hormones on human colon cancer cells. Cancer Res 1992;52:1114-22.

11 Suzuki H, Matsumoto K, Torashima H. Serum levels of gastrin in patients with colorectal neoplasia. Dis Colon Rectum 1988;31:716-17.

12 Kikendall JW, Glass AR, Sobin LH, et al. Serum gastrin is not higher in subjects with colonic neoplasia. Am f Gastroenterol 1992;87:1394-7.

13 Yapp R, Modlin IM, Kumar RR, et al. Gastrin and colorectal cancer. Dig Dis Sci 1992;37:481-4.

14 Penman ID, El-Omar E, Ardill JES, et al. Plasma gastrin concentrations are normal in patients with colorectal neoplasia and unaltered following tumor normal in patients with colorectal neoplasia an
resection. Gastroenterology 1994;106:1263-70.

15 Ciccotosto GD, McLeish A, Hardy KJ, et al. Expression, processing and secretion of gastrin in patients with colorectal carcinoma. Gastroenterology 1995;109:1142-53.

16 Baldwin GS, Casey A, Mantamadiotis T, et al. PCR cloning and sequencing of gastrin mRNA from carcinoma cell lines. Biochem Biophys Res Commun 1990;170:691-7.

17 Baldwin GS, Zhang Q-X. Measurement of gastrin and transforming growth factor $\alpha$ messenger RNA levels in colonic carcinoma cell lines by quantitative polymerase chain reaction. Cancer Res 1992;52:2261-7.

18 Singh $\mathrm{P}, \mathrm{Xu} \mathrm{Z}$, Espeijo R, et al. Incomplete processing of progastrin expressed by human colon cancer cells: Role of noncarboxyamidated gastrins. Am f Physiol 1994;266:G459-68.

19 Finley GG, Koski RA, Melhem MF, et al. Expression of the gastrin gene in the normal human colon and colorectal adenocarcinoma. Cancer Res 1993; 53:2919-26.

20 Rehfeld JF, Bardram L, Blanke S, et al. Peptide hormone processing in tumors: Biogenetic and diagnostic implications. Tumour Biol 1993;14:17483.

21 Rehfeld JF, van Solinge WW. The tumor biology of gastrin and cholecystokinin. Adv Cancer Res 1994;63:295-347.

22 Dockray GJ, Varro A, Dimaline R. Gastric endocrine cells: Gene expression, processing, and targeting of active products. Physiol Rev 1996;76:767-98.

23 Hollande F, Imdahl A, Mantamadiotis T, et al. Glycine-extended gastrin acts as an autocrine growth factor in a non-transformed colon cell line. Gastroenterology 1997;113:1576-88

24 Seva C, Dickinson CJ, Yamada T. Growth-promoting effects of glycineextended progastrin. Science 1994;265:410-12.

25 Nègre F, Fagot-Revurat P, Bouisson M, et al. Autocrine stimulation of AR4-2J rat pancreatic tumor cell growth by glycine-extended gastrin. Int $\mathcal{f}$ Cancer 1996;66:653-8.

26 Singh P, Owlia A, Espeijo R, et al. Novel gastrin receptors mediate mitogenic effects of gastrin and processing intermediates of gastrin on Swiss 3T3 fibroblasts. Absence of detectable cholecystokinin (CCK)-A and CCK-B receptors. F Biol Chem 1995;270:8429-38.

$27 \mathrm{Baldwin} \mathrm{GS}$. The $78 \mathrm{kDa}$ gastrin-binding protein is a candidate receptor for autocrine progastrin. FEBS Lett 1995;359:97-100.

28 Wang TC, Koh TJ, Varro A, et al. Processing and proliferative effects of human progastrin in transgenic mice. 7 Clin Invest 1996;98:1918-29.

29 Kelly RB. Pathways of protein secretion in eukaryotes. Science 1985;230:2531.

30 Baldwin GS. The role of gastrin and cholecystokinin in normal and neoplastic cell growth. $\mathcal{F}$ Gastroenterol Hepatol 1995;10:215-32.

31 Hoosein NM, Kiener PA, Curry RC, et al. Antiproliferative effects of gastrin receptor antagonists and antibodies to gastrin on human colon carcinoma cell lines. Cancer Res 1988;48:7179-83.

32 Baldwin GS. Antiproliferative gastrin/cholecystokinin receptor antagonists target the $78-\mathrm{kDa}$ gastrin-binding protein. Proc Natl Acad Sci USA 1994;91:7593-7.

33 Baldwin GS. Comparison of sequences of the $78 \mathrm{kDa}$ gastrin-binding protein and some enzymes involved in fatty acid oxidation. Comp Biochem Physiol 1993;104B:55-61.

34 Upp JR, Singh P, Townsend CM, et al. Clinical significance of gastrin receptors in human colon cancers. Cancer Res 1989;49:488-92.
35 Imdahl A, Mantamadiotis T, Eggstein S, et al. Expression of gastrin, gastrin/ CCK-B- and gastrin/CCK-C receptors in human colorectal carcinomas. $\mathcal{f}$ CCK-B- and gastrin/CCK-C receptors in
Cancer Res Clin Oncol 1995;121:661-6.

36 Reubi JC, Schaer J-C, Waser B. Cholecystokinin (CCK)-A and CCK-B/ gastrin receptors in human tumors. Cancer Res 1997;57:1377-86.

37 Matsushima Y, Kinoshita Y, Nakata H, et al. Gastrin receptor gene expression in several human carcinomas. Fpn f Cancer Res 1994;85:819-24

38 Smith JP, Stock EA, Wotring MG, et al. Characterization of the CCK-B/gastrin-like receptor in human colon cancer. Am $f$ Physiol 1996;271:R797-805.

39 Bold RJ, Ishizuka J, Townsend CM, et al. Gastrin stimulates growth of human colon cancer cells via a receptor other than CCK-A or CCK-B. Biochem Biophys Res Commun 1994;202:1222-6.

40 Ekundayo AA, Lee CY, Goodlad RA. Gastrin and the growth of the gastrointestinal tract. Gut 1995;36:203-8.

41 Goodlad RA, Wright NA. Growth control factors in the gastrointestinal tract. Baillieres Clin Gastroenterol 1990;4:97-118.

42 Sobhani I, Lehy T, Laurent-Puig P, et al. Chronic endogenous hypergastrinemia in humans: evidence for a mitogenic effect on the colonic mucosa. Gastroenterology 1993;105:22-30.

43 Brinton LA, Gridley G, Hrubec Z, et al. Cancer risk following pernicious anaemia. Br F Cancer 1989;59:810-13.

44 Talley NJ, Chute CG, Larson DE, et al. Risk for colorectal adenocarcinoma in pernicious anemia: a population based cohort study. Ann Intern Med 1989;111:738-42.

45 Chu M, Nielsen FC, Franzen L, et al. Effect of endogenous hypergastrinemia on gastrin receptor expressing human colon carcinoma transplanted to athymic rats. Gastroenterology 1995;109:1415-20.

46 Singh P, Owlia A, Varro A, et al. Gastrin gene expression is required for the proliferation and tumorigenicity of human colon cancer cells. Cancer Res 1996:56:4111-15.

47 Watson SA, Michaeli D, Grimes S, et al. Gastrimmune raises antibodies that neutralize amidated and glycine-extended gastrin-17 and inhibit the growth of colon cancer. Cancer Res 1996;56:880-5.

48 Thumwood CM, Ji H, Baldwin GS. Inhibition of cell proliferation by the cholecystokinin antagonist L-364718. Exp Cell Res 1991;192:189-92.

49 Blackmore M, Hirst BH. Autocrine stimulation of growth of AR4-2J rat pancreatic tumour cells by gastrin. Br f Cancer 1990;66:32-8.

50 Guo Y-S, Baijal M, Jin G-F, et al. Growth-promoting effects of gastrin on mouse colon cancer cells in vitro: Absence of autocrine effects. In Vitro Cell Dev Biol 1990;26:871-7.

51 Beauchamp DR, Townsend CM, Singh P, et al. Proglumide, a gastrin receptor antagonist, inhibits growth of colon cancer and enhances survival in mice. Ann Surg 1985;202:303-9.

52 Imdahl A, Eggstein S, Strik M, et al. Growth of transplanted human colon carcinomas in nude rats: influence of gastrin level modulation and gastrin

53 Piontek MK, Hengels KJ. Differential mode of action of high- and low-affinity CCK/gastrin receptor antagonists in growth inhibition of gastrin-responsive human gastric adenocarcinoma cells in vitro. Anticancer Res 1993;13:715-20.

54 Imdahl A, Eggstein S, Crone C, et al. Growth of colorectal carcinoma cells: regulation in vitro by gastrin, pentagastrin and the gastrin-receptor antagonist proglumide. $\mathcal{F}$ Cancer Res Clin Oncol 1989;115:388-92.

55 Murphy VJ, McBride K, Ji H, et al . Effects of proglumide on cell growth: evidence against an autocrine role for extracellular gastrin. Gastrointestinal Cancer 1995;1:65-70.

56 Harrison JD, Jones JA, Morris DL. The effect of the gastrin receptor antagonist proglumide on survival in gastric carcinoma. Cancer 1990;66: $1449-52$.

57 Watson SA, Crosbee DM, Morris DL, et al. Therapeutic effect of the gastrin receptor antagonist, CR2093 on gastrointestinal tumour cell growth. $\mathrm{Br} \mathcal{F}$ Cancer 1992;65:879-83.

58 Romani R, Howes LG, Morris DL. Gastrin receptor antagonist CI988 inhibits growth of human colon cancer in vivo and in vitro. Aust NZ F Surg 1996;66:235-7.

59 Watson SA, Clifford T, Sykes RE, et al. Gastrin sensitivity of primary human colorectal cancer: The effect of gastrin receptor antagonism. Eur 7 Cancer 1995;31A:2086-92.

60 Johnston PG, Allegra CJ. Colorectal cancer biology: clinical implications. Semin Oncol 1995;22:418-32. 